\title{
Men's Lived Experiences of Perinatal Loss: A Review of the Literature
}

\section{Conflict of Interest Statement}

The authors conclude that there is no perceived conflict of interest. The review was conducted without funding and was part of the co-responding author's prerequisite to fulfil the Master of Social Work.

\section{Corresponding Author: Van Nguyen}

Master of Social Work at Melbourne School of Dentistry and Health Sciences, L7 636 Alan Gilbert Building, Parkville, The University of Melbourne, Victoria. 3010, Australia.

Mobile: 0432478362

Email:vt.nguyen@unimelb.edu.au

\section{Authors:}

Meredith Temple-Smith, Professor and Director of Research Training

Deputy Head at the Department General Practice and Primary Health Care Academic

Centre. 200 Berkeley Street, The University of Melbourne, Victoria. 3010, Australia.

Mobile: 0429858248

Email: m.temple-smith@unimelb.edu.au

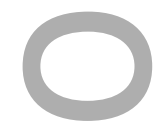

Dr. Jade Bilardi

Senior Research Fellow at Melbourne Sexual Health Centre, 580 Swanston Street, Carlton, Monash University, Victoria. 3053, Australia.

Honorary Research Fellow at the Department General Practice and Primary Health Care Academic Centre. 200 Berkeley Street, The University of Melbourne, Victoria. 3010, Australia.

Mobile: 0402724228

This is the author manuscript accepted for publication and has undergone full peer review but has not been through the copyediting, typesetting, pagination and proofreading process, which may lead to differences between this version and the Version of Record. Please cite this article as doi: $10.1111 / \mathrm{AJ} 0.13041$

This article is protected by copyright. All rights reserved 


\section{Email:jbilardi@mshc.org.au}

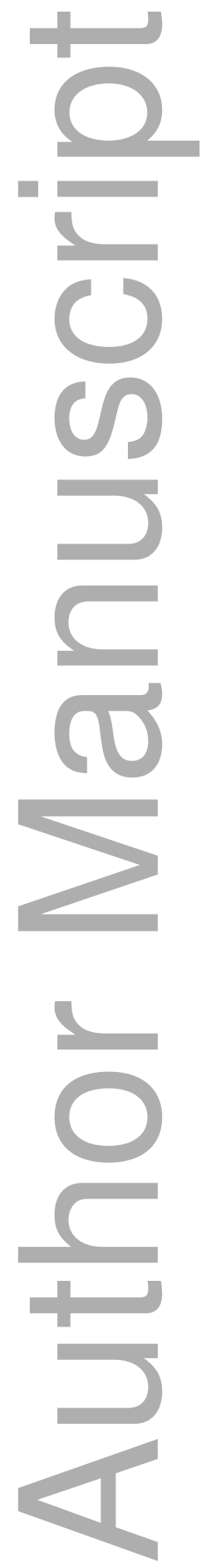

This article is protected by copyright. All rights reserved 
MISS VAN NGUYEN (Orcid ID : 0000-0003-4214-593X)

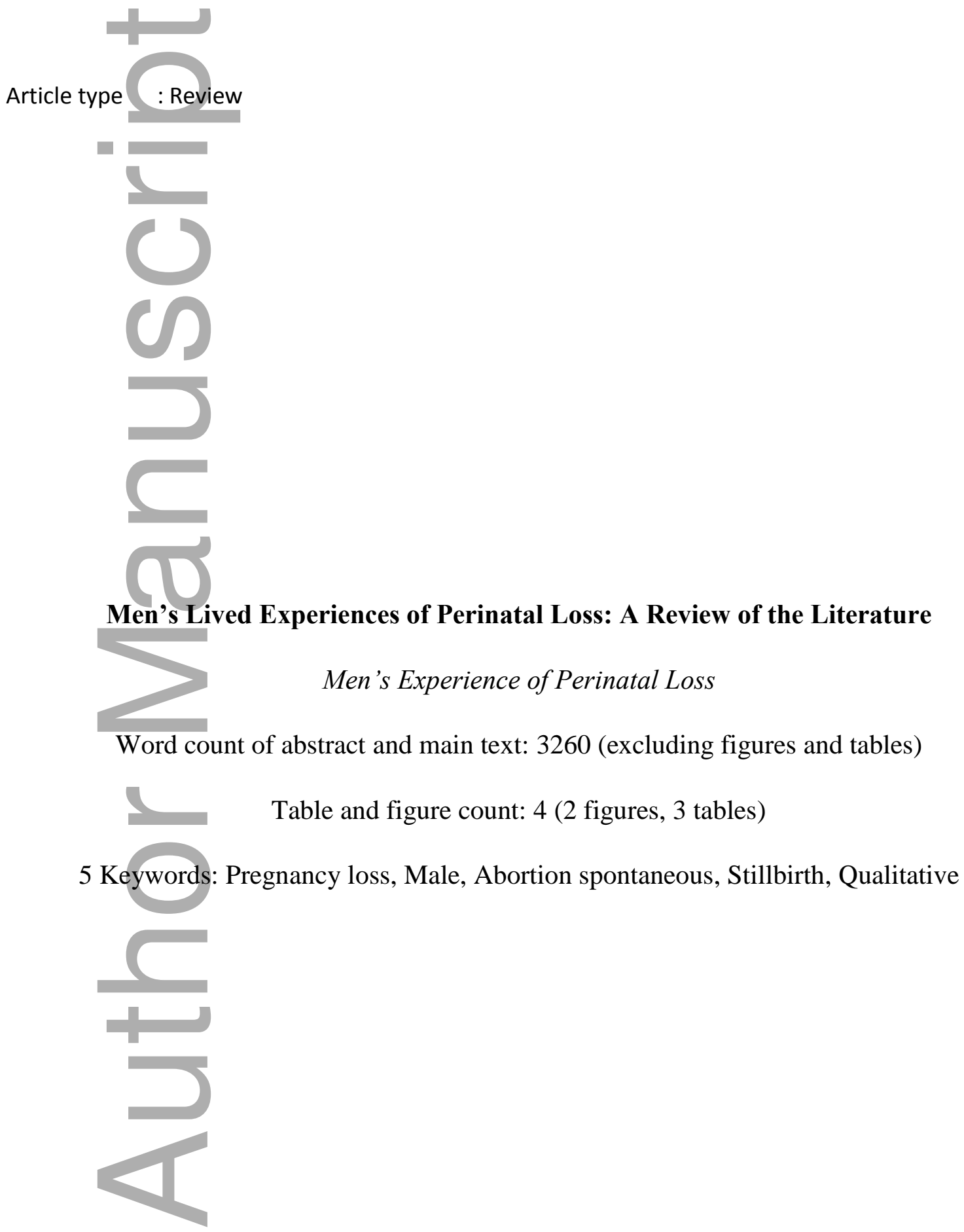

This article is protected by copyright. All rights reserved 


\begin{abstract}
Background

Perinatal loss is often considered an emotionally and physically traumatic event for expectant parents. Whilst there is strong evidence of its impact on women, limited research has independently explored men's lived experiences.

Aim

This scoping review will examine current literature on the lived experiences of men whose partner has experienced a still-birth or miscarriage.

\section{Material and Methods}

The scoping review identified relevant articles by systematically searching through four electronic databases utilising a PRISMA search strategy. Strict inclusion and exclusion criteria were applied to articles. The articles' reference lists were further scrutinized until no further articles that met the criteria were located. Fifteen articles were located including 14 qualitative studies and one non-peer reviewed academic article. Articles were thematically analysed.
\end{abstract}

Results

The review identified three major themes that are particularly pertinent to shaping the lived experiences of men whose partner has suffered a perinatal loss: 1) pregnancy attachment and the aftermath, 2) supporting their partner and being supported 3) impacts upon future pregnancies.

Conclusion

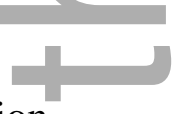

Perinatal loss can have negative implications for men's psychological and social well-being. Across the studies men had different levels of attachments to the pregnancy, influencing their emotional responses to the loss. Men perceived their primary role as being a supporter to their partners but received limited support themselves. Men often reported that their safe and trusting attitudes toward pregnancy had forever changed. Further areas of research are recommended in hopes of enhancing supports for men, and consequently their partners and families, who experience perinatal loss. 


\section{Background}

In Australia alone, there are an estimated 150, 000 incidences of perinatal loss experienced by women every year. Approximately 147,000 of these losses are due to miscarriages and 1750 are still-births. ${ }^{1}$ In Australia, perinatal loss before 20 weeks is termed a miscarriage and after 20 weeks, a still-birth. ${ }^{2}$ Bereaved couples experiencing perinatal loss, particularly miscarriage, often find themselves alone in coping with their distress as they are excluded from the traditional grieving processes normally offered to deaths more commonly perceived as legitimate. ${ }^{3}$ However, strong evidence exists of the significant psychosocial impact of perinatal loss on women, which has resulted in a number of interventions being advocated to address their needs. ${ }^{4}$ In Australia, the establishment of several organisations including Sands Australia, The Pink Elephants Support Network and Bears of Hope offer services to address perinatal loss including support groups, counselling services and education for health-care professionals regarding best care practices. Unfortunately, limited support is tailored to and directed to men despite the potential implications of the experience on their well-being.

Unfortunately, because women physically bear the pregnancy, there appears to be an underlying societal assumption that perinatal loss only impacts them. The disenfranchisement of men's grief experiences can have detrimental impacts upon their physical health and wellbeing. Quantitative studies reveal that men who internalise their grief emotions have greater difficulty seeking support. Instead, they are more likely to utilise active-avoidance coping strategies. This may include withdrawing emotionally or physically and adopting compensatory behaviours such as increasing their tobacco, drug or alcohol consumption. 5,6 Consequently, as evidenced in Conway and Russel's (2000) study, ${ }^{7}$ men were at a higher risk than women of developing complicated and delayed grief reactions for up to two years after the experience. The internalisation of their grief emotions may also have negative implications for their intimate relationships. In a study by Swanson, Karmali, Powell \& Pulvermakher (2003), ${ }^{8}$ women who perceived their partners as engaged with caring behaviours and willing to discuss their feelings experienced fewer negative consequences in their marriage than those who were not. Evidently, men's understanding and lived experiences of perinatal loss can have implications on not only their individual well-being but also their relationships with partners and family members.

The aim of this review was to explore and describe what is known in the literature about the experiences of men whose partner has suffered perinatal loss, with a particular focus on 
miscarriage and still-birth. The review examines the extent, range and nature of research within this area to identify gaps in the existing literature. ${ }^{9}$ Through mapping the scope of the research, the review will contribute to evidence-based practice, which may be utilised by both health and allied health professionals working with men, women, and families within this domain. Furthermore, it seeks to highlight themes of perinatal loss, which may be beneficial to both validate men's experiences and be informative to families for whom this topic is of concern.

What is known about the topic?

- Miscarriage and still-birth can be a traumatic occurrence for expecting parents; however, there is limited knowledge on men's experiences and the implications of a perinatal loss on their psychological and social wellbeing.

What does this paper add?

- This paper confirms that perinatal loss can be an emotionally devastating and isolating event for men. This has implications for their psychological and social well-being, intimate relationships and future plans for fatherhood.

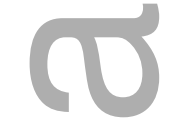

\section{Search Strategy}

\section{Methodology}

Relevant articles were located by systematically searching four databases including Medline (Ovid), PsychINFO (Ovid), CINAHL (EBSCO), and Families and Societies (EBSCO). The search terms can be found in Table 1 .

\section{Inclusion and Exclusion Criteria}

The review included articles that predominantly explored the men's experiences of perinatal loss. This includes studies that explored both men and women's experiences as long as their results were separately analysed. It also included women's perceptions of men's experiences, which had the potential to provide further depth to the review. The search included only journal articles and did not include thesis or book chapters. As narrative reviews do not evaluate the quality of studies, non-peer reviewed articles were included as long as they were published in an academic journal. ${ }^{9}$ Articles had to be published during or after 2000 in an attempt to keep the review as contemporary as possible. This is consistent with relevant literature contending that men's roles as expecting fathers have undergone a significant cultural shift in the $21^{\text {st }}$ century with a growing expectation for men to be more involved in 
the pregnancy experience. ${ }^{10}$ This may influence their grief experiences and reactions to perinatal loss. ${ }^{11}$ Neonatal death was also excluded from the search.

[Insert Table 2. Inclusion and Exclusion]

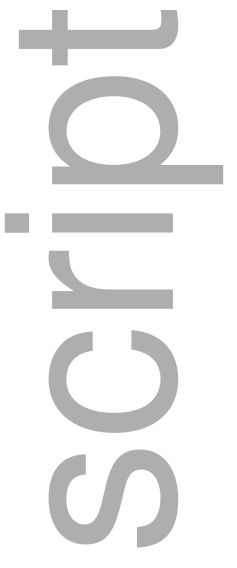

The search results produced a total of 474 articles across four databases. Inclusion and exclusion criteria were then applied to the article titles and abstracts. Screenings of 474 titles and abstracts resulted in the identification of 39 articles that fulfilled the inclusion criteria. The predominant reason for excluding the 435 articles was their focus on women's medical and gynaecological needs during perinatal loss rather than men's experiences. Sixteen of these articles were found to be duplicates and therefore removed. Inclusion and exclusion criteria were applied to the remaining 23 articles. Thirteen articles met the inclusion criteria and ten articles were excluded. The subsets were independently checked by all three authors (VN, MTS, JB). The reference lists of the final 13 articles were hand searched, resulting in an additional two articles being located. In total, fifteen papers were included within this review. Figure 1 below illustrates the article extraction process.

[Figure 1 inserted here]

\section{Data Extraction and Analysis}

Data from the studies, including study aims, design and participant characteristics was ordered into a Microsoft Excel (Microsoft Corporation, Redmond, WA, USA) spreadsheet. A data charting form to determine what information to extract in order to answer the review question was developed. ${ }^{9}$ Qualitative content analysis techniques according to Levac, Colquhoun \& Brien (2010) ${ }^{9}$ were adopted to review the 15 articles. The content analysis was an iterative process where text within articles was analysed and inductively coded, the codes were then recorded into a matrix framework and later categorised based on subject matter, 
assigned meanings, contrasts and comparisons. This was performed several times with one researcher revisiting the categories to identify contradictory evidence or provide supporting evidence for conclusions until saturation was reached. ${ }^{10}$ In order to ensure trustworthiness of the content analysis, throughout the process, categorisation of codes was reviewed by two independent researchers within the field (JD, MTS). After consultation between all three authors (VN, JD, MTS), consensus was reached regarding the categorisation of the data into three overarching themes: pregnancy and the aftermath; supporting and being supported; impact upon future pregnancies. A group of related subthemes were identified that underpinned major principles.

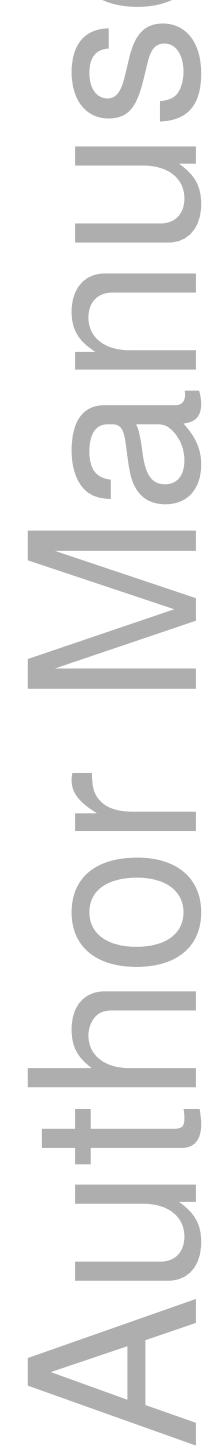




\section{$\underline{\text { Results }}$}

\section{[Insert Table 3. Summary of Results]}

\section{Study Characteristics}

The final collection of articles included 14 qualitative articles ${ }^{12-25}$ and one non-peer reviewed article published in an academic journal. ${ }^{26}$ The non-reviewed article ${ }^{26}$ was included, as scoping reviews are not required to assess the quality of identified articles. ${ }^{9}$ In addition, the authors had prior knowledge that relevant literature addressing the review topic was scarce. It was concluded that the inclusion of the non-reviewed article would provide valuable insight into a topic that was seldom addressed.

It is noted that although the scoping review identified articles that could encapsulate men's lived experiences of perinatal loss, there was a wide variation in each article's specific objectives and scope. Although the articles each had different aims and objectives, ultimately, they sought to contribute to the current knowledge base of men's experiences regarding perinatal loss. All qualitative studies utilised semi-structured and in-depth interviews as part of their methodology. In studies that had couples, authors interviewed each participant separately from their partner $12,13,16,18,22$.

A majority of the qualitative studies were cross-sectional in design while two were longitudinal studies. ${ }^{14,15}$ All qualitative studies adopted a phenomenological approach to data analysis with the exception of one, which adopted the constructionist grounded theory approach. $^{17}$

In terms of study participants, six articles utilised purposive sampling and only included men

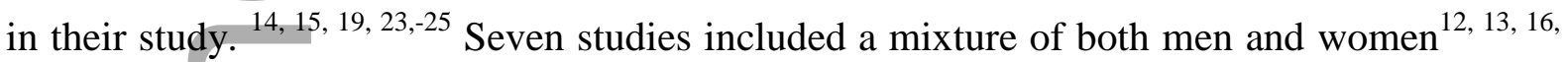
$18,21,22$ with only one study identifying purposive sampling to actively seek out and include male participants. ${ }^{21}$ One study collected data only from women ${ }^{17}$ and one study included insight from midwives and nurses working the perinatal area. ${ }^{19}$ Across the studies, a total of 100 men were interviewed about their experiences. The samples of men from studies were consistently small ranging from a minimum of 4 men $^{14}$ to a maximum of 14 men. ${ }^{19}$ It is noted that three articles specifically included men from culturally and linguistically diverse backgrounds. ${ }^{12,13,18}$ All interviews with participants were conducted in English except for two studies with participants being interviewed in their native language and then professionally translated into English. ${ }^{17,18}$ 
The majority of studies originated from the United States [ $n=4]$ followed by Australia [ $n=3$ ], Ireland [ $\mathrm{n}=3]$ and one each from Israel, Sweden, Switzerland, and South Africa. It is noted that there were no articles originating from East Asian nations nor were any participants in the located articles from this region.

\section{$\underline{\text { Discussion }}$}

The question "What is known about the lived experiences of men whose partners have undergone perinatal loss?" framed the synthesis of the literature. In answering the proposed question, the following three key themes and subthemes emerged:

[Insert Figure 2. Key themes and subthemes]

\section{Pregnancy and the Aftermath}

\section{Attachment in-Utero}

The way in which men processed perinatal loss was related to how they perceived the pregnancy. Across the studies, men had differing concepts of when the pregnancy came to represent a living child. One major aspect that influenced their perceptions was witnessing the first signs of life usually through a techno-mediated relationship e.g.: seeing an ultrasound or hearing a heartbeat. Men who perceived the pregnancy as an irreplaceable infant expressed stronger grief responses and had greater difficulties in coping. ${ }^{14,15,19,22,25}$ In comparison, men who did not conceive the pregnancy yet as an individual child but rather as the loss of a potential child expressed feelings of shock and disappointment, however this was not sustained over a period of time. ${ }^{12-14,18}$ Although gestation can be one factor influencing attachment, there is limited discussion on men who had experienced difficulties conceiving or perhaps utilised in vitro fertilisation, and if this could potentially affect their perceptions and therefore attachments to the pregnancy.

\section{Identity Formation After Perinatal Loss}

Discrepancies were also evident in men's self-identification as a 'father' after a perinatal loss. For births where physical remains of an infant existed, generally in late term miscarriage or stillbirth, men had the opportunity to engage in post-birth care. In both Bonettte \& Broom $(2012)^{15}$ and Samuelsson et al. (2001)'s ${ }^{24}$ studies, men reported the time spent with their stillborn as a valuable fathering experience. Tokens of remembrance including handprints and photographs were deemed invaluable to assist men understand their loss afterwards, solidifying their identity as a grieving father. However, in McCreight's (2004) study, ${ }^{19}$ 
contact with stillborn remains had a detrimental and traumatic effect on the men. Participants reported that they were not prepared by staff and had no prior knowledge of how to handle the remains.

In contrast, there seemed to be limited formal mechanisms or rituals in place to validate men's grief in the event of miscarriage, particularly in the early stages of pregnancy. Studies focusing solely on miscarriage included no discussion of any post-birth care routines or tokens of remembrance within a hospital setting. ${ }^{12,13,18,20,25}$ While stillbirths had clear, legal processes regarding burial arrangements in the cases of miscarriage, burial protocols widely differed between hospitals and were dependent upon the knowledge and sensitivity of medical and nursing staff involved. ${ }^{19}$ As a result, men in McCreight's (2004) ${ }^{19}$ and Meaney et.al's (2017) ${ }^{21}$ studies commonly expressed uncertainty in their identity as a father particularly those who experienced early miscarriages and who did not have the opportunity to validate their loss through customary protocols. Men in these two studies experienced early miscarriages from as far back as 20 years prior to the interviews, suggesting that perinatal loss can lead to ambiguous grief, complicating their capacity to process and understand the event even decades afterwards as the loss and its associated meaning to men may evolve over time.

\section{Supporting and Being Supported}

\section{Men Supporting their Partner}

Consistent throughout the studies is that men viewed their primary role as being the 'supporter' for their partners. In Hamama-Raz et al. (2010)'s study ${ }^{18}$ of five Jewish couples who had experienced miscarriages, men commonly reported that focusing on their partner provided them with strength and purpose, enabling them to bypass their own pain. Whilst this can provide men with a means to cope, to fulfill this role a majority felt pressured to hide their emotions altogether to avoid distressing their partner. ${ }^{12,13,15,21,23,24,25}$ Yet in Samuelsson et al. $(2001)^{24}$, men recollected that the desire to preserve their role as a supporter continued even when they recognized that their partners wanted to see emotional vulnerability. In the case study exploring a psychologist's work with a prisoner who experienced a miscarriage, ${ }^{26}$ anger for instance was perceived as the only 'valid' masculine response in face of distress and grief, particularly in a prison context where emotional vulnerability was perceived as a flaw. This has implications for men's families overall, with women noting that they could not 
turn to their partners for support if they feared responses of anger and blame, leading to martial conflict. ${ }^{17}$ In other instances, however, positive growth in marriages was noted such as greater intimacy and mutual understanding as differences in grieving and coping styles were negotiated or reconciled over time. ${ }^{16,18,24}$

\section{Being Supported by Friends, Family and Society}

Across the studies, men noted accounts of being 'overlooked' not only by health professionals but also friends and family who would often only enquire about their partner's well-being. ${ }^{12,13,15,19}$ In Bonnette \& Broom's (2012) study of 12 Australian men who experienced a still-birth, ${ }^{15}$ disenfranchisement by others in society contributed to them perceiving their grief as being less legitimate than their partners. Men reported tension between being recognised as both a 'strong', supportive husband but also a vulnerable, grieving father. ${ }^{15,19,24}$ These conflicting but intertwined social positions and responsibilities can be a source of stress and turmoil, hindering men's willingness to request help from others. In contrast, the few men who received positive reinforcement from hospital staff, friends, family or employers felt that their sense of loss was validated and enabled them to express their grief to others. ${ }^{25}$ This suggests that health professionals, usually being the first people to have contact with couples experiencing perinatal loss, have a role in validating men's grief experience, which could potentially mitigate negative consequences in the future. Further supports are suggested, particularly targeted towards men. However what form of supports men might find beneficial has not been explored within the articles.

\section{Impact Upon Future Pregnancies}

\section{Coping with Subsequent Pregnancies}

As mentioned above, all men had differing attachments to the loss. However, despite the discrepancies, consistent amongst men across the studies was that their 'innocent, trusting approach to a new pregnancy had been lost forever (Samuelsson et al. pp.128). ${ }^{24}$ In Meaney et al. (2017), ${ }^{21}$ five men expressed reluctance at considering another pregnancy in the month following a stillbirth due to their fears and anxieties for both their own and their partners' wellbeing. Perinatal loss has the potential to alter men's parental aspirations altogether, however the articles did not discuss if having previous living children influenced this decision. Four studies explicitly addressed men's experiences of subsequent pregnancies after a perinatal loss. ${ }^{14,16,22,23}$ The experience of a past perinatal loss infiltrated every aspect of subsequent pregnancies. O'Leary $(2005)^{26}$ explored couples' experiences of ultra-sounds 
during a subsequent pregnancy and found that men were unprepared for memories of their previous loss to resurface during the "seemingly routine exam (pp. 192)." Across the studies, men reported heightened feelings of anxiety and increased vigilance of both mother and the potential infant, along with hesitation at expecting a positive outcome. ${ }^{14,16,22,23}$ However, they felt unable to discuss this with their partners, causing some men to feel additional stress and isolation. ${ }^{14,16,22,23}$

\section{Positive Growth and Transformation}

If a subsequent pregnancy was successful, positive personal growth could occur as men noted a newfound appreciation for the fatherhood experience and increased capacity to handle stressful life moments. ${ }^{14,16,24}$ Some men noted that they still remembered and tried to maintain a bond with their previous loss ${ }^{16,24}$ In Abboud and Liamputtong's (2003) study, ${ }^{13}$ however, men chose to focus on their following, living children rather than ruminating on the past miscarriage (pp. 51). It should be noted that an overwhelming majority of the qualitative studies were cross-sectional in design [ $n=12]$. Hence studies' findings only captured men's views at one singular point in time and were conducted after the event or after the conception of another pregnancy providing limited insight into if or how their understanding of the event and sense of loss evolved over time. This can be particularly poignant for men who experienced multiple perinatal losses or were never able to conceive any living children.

The review has identified three broad themes which have been relevant to providing insight to men's understanding and perceptions of losing a potential child to miscarriage or stillbirth. Although men's feelings and intensity of grief were intrinsically linked to their perceptions of pregnancy and, in particular gestation, nevertheless perinatal loss had wider implications for men's psychological wellbeing, relationships and future plans for fatherhood. The review advocates further research into men's experiences of perinatal loss, and it is anticipated that by expanding such research we can identify potential avenues to support men throughout this process, improve health service delivery and ultimately enhance outcomes for all those who experience perinatal loss, regardless of their gender.

\section{$\underline{\text { Limitations }}$}

Scoping reviews are not required to assess the quality of identified articles ${ }^{27}$ which is a limitation as the analysis is dependent upon the quality of the studies located at the time. However, as this is the first Australian narrative review of men's lived experiences of perinatal loss, it does provide a valuable contribution to the research area. 


\section{Reference List}

1 cope.org.au. Centre of Perinatal Excellence Pregnancy Loss, 2013 [Cited April 19, 2018]. Avaliable from: http://cope.org.au/pregnancy/pregnancy-loss/.

2 Brier, N. Grief Following a Miscarriage: A Comprehensive Review of the Literature. Journal of Women's Health 2008; 17 (3): 451-461.

3 Lang, A., Fleiszer, A. R., Duhamel, F., et al. (2011). Perinatal Loss and Parental Grief: The Challenge of Ambiguity and Disenfranchised Grief. OMEGA - Journal of Death and Dying 2011; 63(2): 183-196.

4 Rowlands, I. J., \& Lee, C. "The silence was deafening": Social and health service support after miscarriage. Journal of Reproductive and Infant Psychology 2010; 28(3): 274-286.

5 Due, C., Chiarolli, S., \& Riggs, D. W. The impact of pregnancy loss on men's health and wellbeing: A systematic review. BMC Pregnancy and Childbirth 2017; 17(1): 1-14.

6 Johnson, M. P., \& Baker, S. R. (2004). Implications of coping repertoire as predictors of men's stress, anxiety and depression following pregnancy, childbirth and miscarriage: A longitudinal study. Journal of Psychosomatic Obstetrics and Gynecology 2004; 25(2): $87-98$.

7 Conway, K \& Russell G. Couple's grief and experience of support in the aftermath of miscarriage. British Journal of Medical Psychology 2000; 73: 531-545.

8 Swanson, K. M., Karmali, Z. A., Powell, S. H., \& Pulvermakher, F. Miscarriage effects on couples' interpersonal and sexual relationships during the first year after loss: Women's perceptions. Psychosomatic Medicine 2003; 65: 902-910.

9 Levac, D., Colquhoun, H., \& O’Brien, K. (2010). Scoping studies : advancing the methodology. Implementation Science 2010; 5:69.

10 Julien, H. Content Analysis. In: Given, L (ed.). The SAGE Encyclopedia of Qualitative Research Methods. London: SAGE Publications; 2008; 120-121.

11 Cabrera, N. J., Tamis-lemonda, C. S., Bradley, R. H., et al. Fatherhood in the Twenty-First Century. Child Development: 2000; 71(1): 127-136.

12 Abboud, L. N., \& Liamputtong, P. Pregnancy Loss. Social Work in Health Care: 2002; 
36(3): 37-62.

13 Abboud, L., \& Liamputtong, P. When pregnancy fails: Coping strategies, support networks and experiences with health care of ethnic women and their partners. Journal of Reproductive and Infant Psychology: 2005; 23(1): 3-18.

14 Armstrong, D. Exploring fathers' experiences of pregnancy after a prior perinatal loss. MCN The American Journal of Maternal Child Nursing 2001; 26(3): 147-153.

15 Bonnette, S., \& Broom, A. On grief, fathering and the male role in men's accounts of stillbirth. Journal of Sociology: 2011. 48(3): 248-265.

16 Campbell-Jackson, L., Bezance, J., \& Horsch, A. “A renewed sense of purpose:” Mothers' and fathers' experience of having a child following a recent stillbirth. BMC Pregnancy and Childbirth: 2014; 14: 423.

17 Corbet-Owen, C. Women's perceptions of partner support in the context of pregnancy loss(es). South African Journal of Psychology 2003; 33(1): 19-27.

18 Hamama-Raz, Y., Hemmendinger, S., \& Buchbinder, E. The unifying difference: Dyadic coping with spontaneous abortion among religious Jewish couples. Qualitative Health Research 2010; 20(2): 251-261.

19 McCreight, B. S.. A grief ignored: Narratives of pregnancy loss from a male perspective. Sociology of Health and Illness 2004; 26(3): 326-350.

20 Meaney, S., Everard, C. M., Gallagher, S., \& O’Donoghue, K. Parents' concerns about future pregnancy after stillbirth: a qualitative study. Health Expectations 2017; 20: 555562.

21 Meaney, S., Corcoran, P., \& Spillane, N. (2017). Experience of miscarriage: an interpretative phenomenological analysis. BMJ Open 2017; 7: e011382. doi: /10.1136/bmjopen-2016.

22 O'Leary, J. The trauma of ultrasound during a pregnancy following perinatal loss. Journal of Loss and Trauma 2005; 10:183-204.

23 O’Leary, J., \& Thorwick, C. Father's Perspectives During Pregnancy, Postperinatal Loss. Journal of Obstetric Gynecologic and Neonatal Nursing 2006; 35(1): 78-86.

24 Samuelsson, M., Rådestad, I., \& Segesten, K. A Waste of Life: Fathers’ Experience of 
Losing a Child Before Birth. BIRTH 2001; 28(2): 124-130.

25 Wagner, N. J., Vaughn, C. T., \& Tuazon, V. Fathers' Lived Experiences of Miscarriage.

The Family Journal: Counselling and Therapy for Couples and Families 2018; 26(2):

193-199.

26 Rinehart, M. S., \& Kiselica, M. S. Helping men with the trauma of miscarriage.

Psychotherapy, Research, Practice and Training 2010; 46(3): 288-295.

27 Arksey, H., \& O’Malley, L. (2005). Scoping studies: Towards a methodological framework. International Journal of Social Research Methodology: Theory and Practice 2005; 8(1): 19-32.

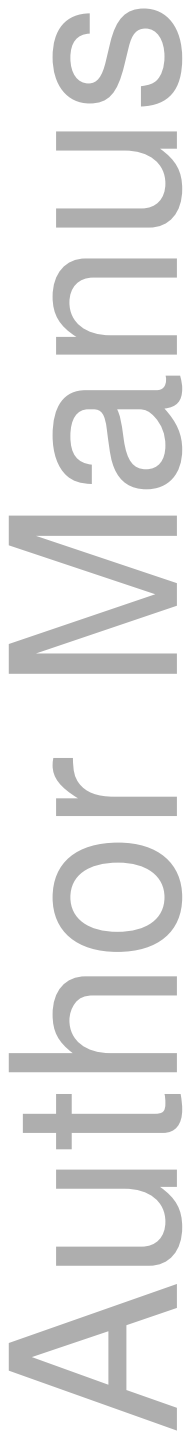


Table 1: Database search strategy

\begin{tabular}{|l|l|l|}
\hline Perinatal Loss & Men's & Experience \\
\hline "Antenatal loss" & Men* & "Lived experience" \\
\hline "Prenatal loss" & Man* & "Life experience" \\
\hline "Pregnancy loss" & Male* & Attitude* \\
\hline Spontaneous & Spous* & Perspective* \\
\hline "Perinatal death" & Husband* & \\
\hline "Perinatal loss" & Father* & Perception* \\
\hline Miscarriage & Dad* & View* \\
\hline Stillbirth & Paternal* & Feeling* \\
\hline & Partner* & Thought* \\
\hline
\end{tabular}

The * acts as a truncation symbol, allowing the search to include all possible endings for the term.

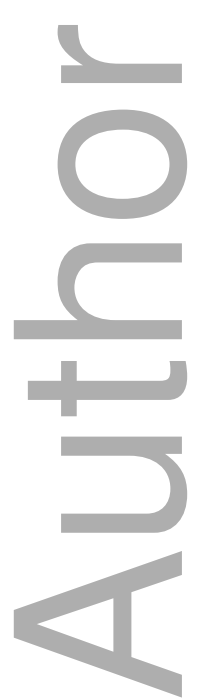


Table 2. Inclusion and Exclusion Criteria

\section{Inclusion}

Men of any age or country whose partner

have experienced a miscarriage or still-

birth

Study Focus

\section{is}

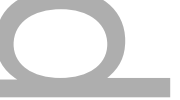

口

1

ran

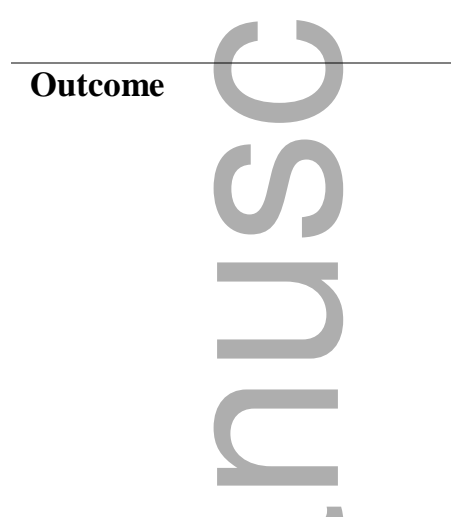

Focus on miscarriage, still-birth and neonatal death but analyzed data separately
Focus on the experiences of men in relation to miscarriages or still-birth. This can be told by men themselves, their partners, family members or health professionals.

The sample included experiences of men and women but analyzed data separately

\section{Exclusion}

Men whose partner have experienced a neonatal

death, undergone a voluntary abortion

Studies where qualitative data does not distinguish between type of pregnancy loss. i.e. Includes miscarriages, still-birth and neonatal death without specifying which loss is being commented on. Focus on the experiences of women or health

\section{Primary or Secondary}

Data

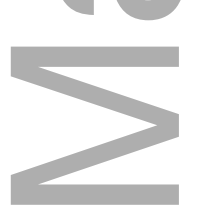

Articles in English or with sufficient translation

Collected primary data on the experiences of men or personal recollections from the author professionals.

The sample included experiences of men and women but analyzed data together e.g.: as a couple or family Articles in languages other than English with no sufficient translation

Secondary analysis of primary data, review of the literature

Book chapters, theses/dissertation

\begin{tabular}{lll}
\hline Publication Type & Journal Articles, industry reports, grey & Book chapters, theses/dissertation \\
& literature & \\
\hline Methodology & Qualitative studies & Quantitative studies or mixed-design studies \\
\hline Date & Studies conducted after 2000 & \\
& & \\
& &
\end{tabular}


Table 3. Summary of Results

\begin{tabular}{|c|c|c|c|c|c|c|c|c|}
\hline & $\begin{array}{l}\text { Author } \\
\text { Year }\end{array}$ & Title & Journal & Country & Study Design & Participants & Aim & Key Findings \\
\hline 1 & $\begin{array}{l}\text { Abboud \& } \\
\text { Liamputtong, } \\
2002\end{array}$ & $\begin{array}{l}\text { Pregnancy } \\
\text { loss: what it } \\
\text { means to } \\
\text { women who } \\
\text { miscarry and } \\
\text { their partners. }\end{array}$ & $\begin{array}{l}\text { Social Work in } \\
\text { Health Care }\end{array}$ & Australia & $\begin{array}{l}\text { Phenomenological } \\
\text { approach. } \\
\text { In-depth, semi- } \\
\text { structured interviews. }\end{array}$ & $\begin{array}{l}6 \text { women and their partners } \\
\text { from ethnic backgrounds. }\end{array}$ & $\begin{array}{l}\text { Examine the experiences and insights } \\
\text { of women, and their partners who } \\
\text { have suffered a miscarriage. }\end{array}$ & $\begin{array}{l}\text { Men reported intense feelings after event but } \\
\text { these diminished quicker than their partners. } \\
\text { All men reported that they had to support their } \\
\text { partners first throughout the experience. }\end{array}$ \\
\hline 2 & $\begin{array}{l}\text { Abboud \& } \\
\text { Liamputtong, } \\
2005\end{array}$ & $\begin{array}{l}\text { When } \\
\text { pregnancy } \\
\text { fails: Coping } \\
\text { strategies, } \\
\text { support } \\
\text { networks and } \\
\text { experiences } \\
\text { with the } \\
\text { health care of } \\
\text { ethnic women } \\
\text { and their } \\
\text { partners. }\end{array}$ & $\begin{array}{l}\text { Journal of } \\
\text { Reproductive } \\
\text { and Infant } \\
\text { Psychology }\end{array}$ & Australia & $\begin{array}{l}\text { Phenomenological } \\
\text { approach. } \\
\text { In-depth, semi- } \\
\text { structured interviews. }\end{array}$ & $\begin{array}{l}\text { Same participants as } \\
\text { above. }\end{array}$ & $\begin{array}{l}\text { Examine coping strategies, support } \\
\text { networks and experiences of health } \\
\text { care among a small group of ethnic } \\
\text { women and their partners who have } \\
\text { experienced a miscarriage. }\end{array}$ & $\begin{array}{l}\text { All men reported that they coped by attempting } \\
\text { to return to normalcy. Men perceived social } \\
\text { support as beneficial for their partners' } \\
\text { recovery, not theirs. Mixed attitudes towards } \\
\text { provided health services. }\end{array}$ \\
\hline 3 & 눈 & $\begin{array}{l}\text { Exploring } \\
\text { fathers' } \\
\text { experiences } \\
\text { of pregnancy } \\
\text { after a prior } \\
\text { perinatal loss }\end{array}$ & $\begin{array}{l}\text { The American } \\
\text { Journal of } \\
\text { Maternal Child } \\
\text { Nursing }\end{array}$ & $\begin{array}{l}\text { United } \\
\text { States }\end{array}$ & $\begin{array}{l}\text { Phenomenological } \\
\text { approach. Two } \\
\text { interviews conducted. }\end{array}$ & $\begin{array}{l}4 \text { men who experienced a } \\
\text { loss in the second or third } \\
\text { trimester and are currently } \\
\text { in a subsequent pregnancy. }\end{array}$ & $\begin{array}{l}\text { Explore the meaning of previous loss. } \\
\text { Examine the impact of the loss on } \\
\text { men's attachments to the current } \\
\text { pregnancy. } \\
\text { Provide direction for nursing staff in } \\
\text { the area. }\end{array}$ & $\begin{array}{l}\text { Men reported differences in their past and } \\
\text { current pregnancy experience. } \\
\text { Men reported fear of expecting a positive } \\
\text { outcome. Themes includes coping with grief, } \\
\text { supporting partner and the importance of } \\
\text { milestones in subsequent pregnancy. }\end{array}$ \\
\hline
\end{tabular}

This article is protected by copyright. All rights reserved 
Table 3. Summary of Results

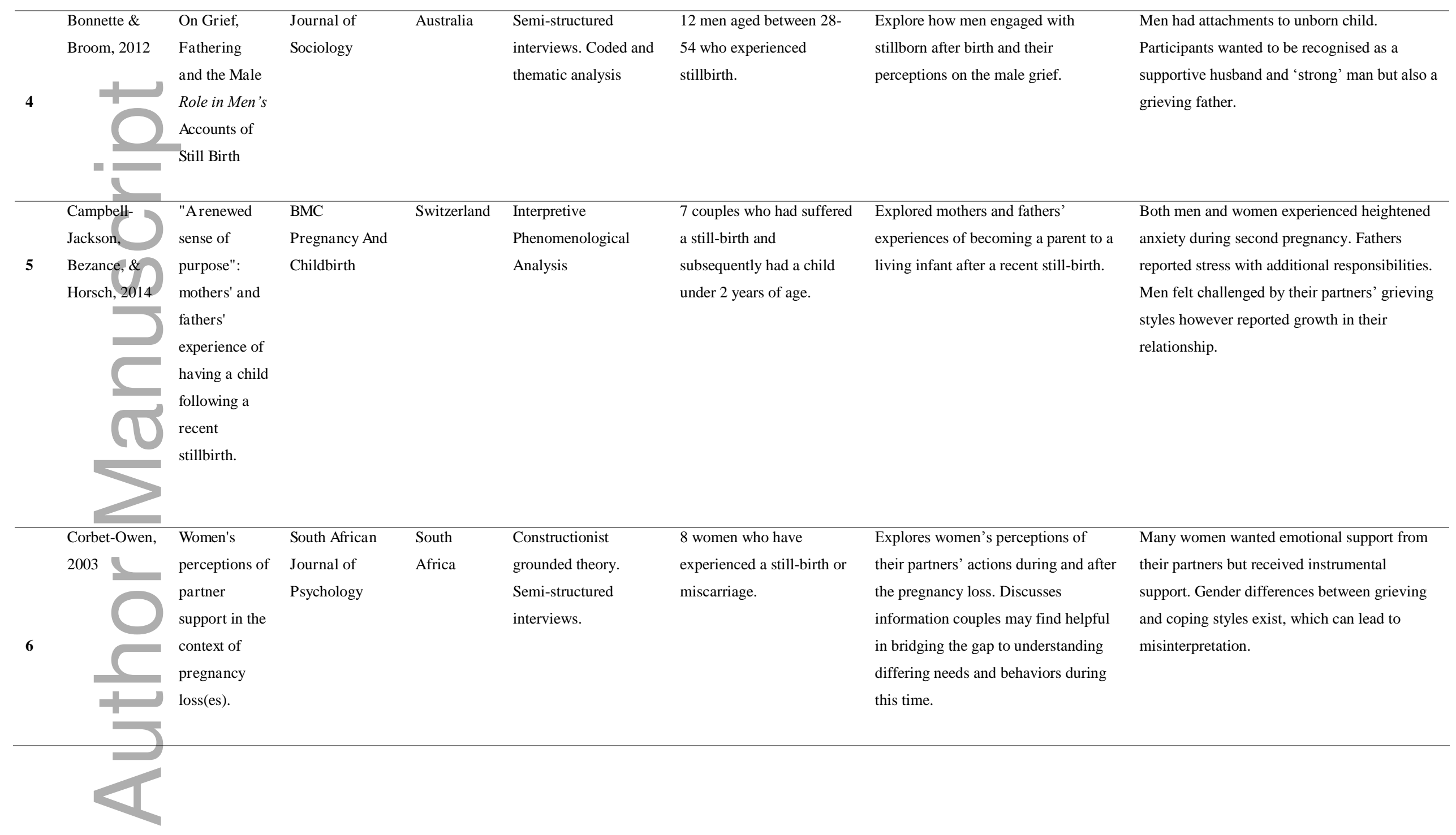

This article is protected by copyright. All rights reserved 
Table 3. Summary of Results

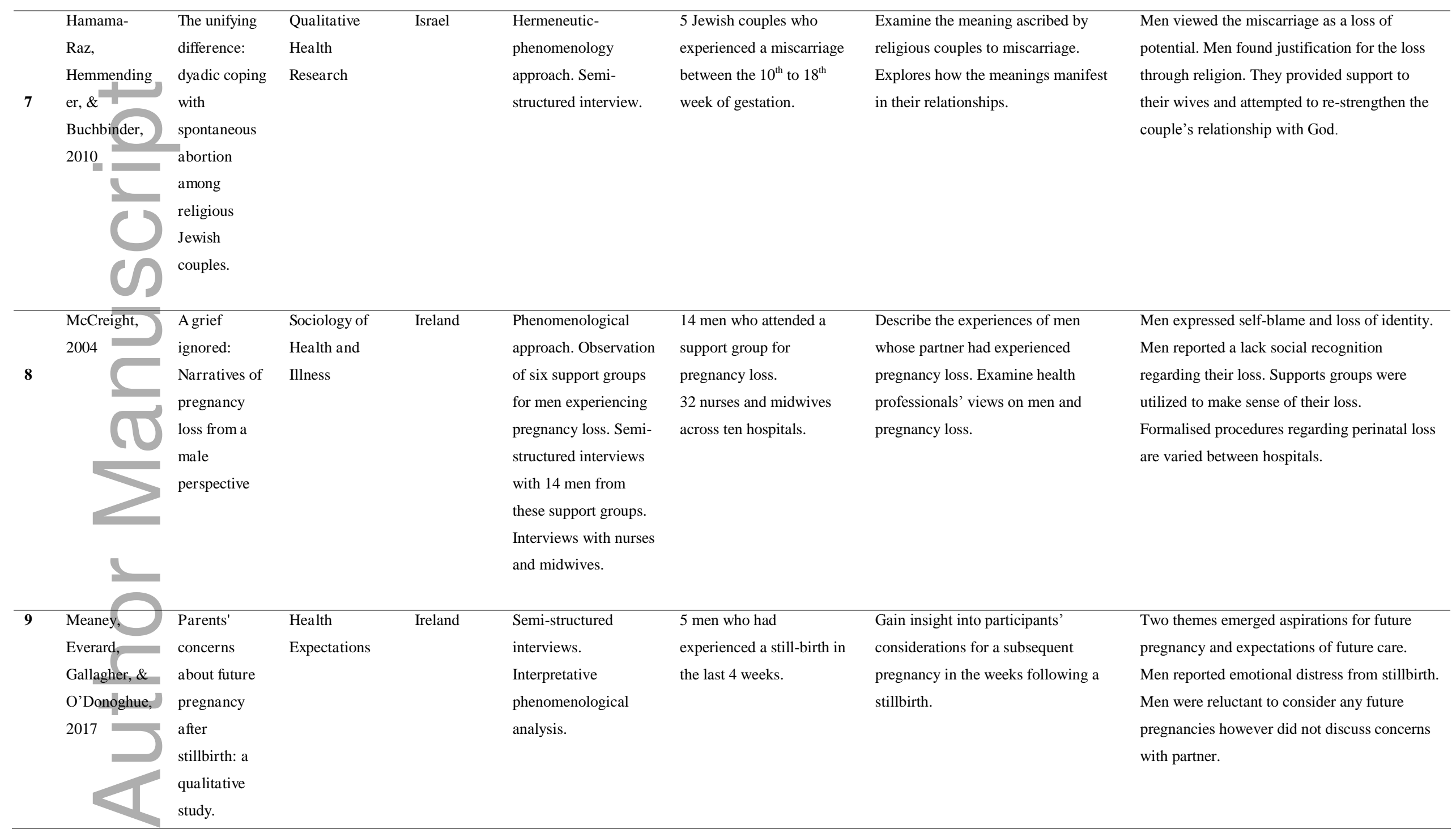

This article is protected by copyright. All rights reserved 
Table 3. Summary of Results

\begin{tabular}{|c|c|c|c|c|c|c|c|c|}
\hline 10 & $\begin{array}{l}\text { Meaney, } \\
\text { Corcoran, \& } \\
\text { Spillane, } \\
\end{array}$ & $\begin{array}{l}\text { Experience of } \\
\text { miscarriage: } \\
\text { an } \\
\text { interpretative } \\
\text { phenomenolo } \\
\text { gical analysis }\end{array}$ & BMJ Open & Ireland & $\begin{array}{l}\text { Phenomenological } \\
\text { approach. In-depth } \\
\text { semi-structured } \\
\text { interviews. }\end{array}$ & $\begin{array}{l}6 \text { men who had } \\
\text { experienced a miscarriage. }\end{array}$ & $\begin{array}{l}\text { Explore men's account of miscarriage, } \\
\text { their future expectations of pregnancy } \\
\text { and the miscarriage management. }\end{array}$ & $\begin{array}{l}\text { Acknowledgment of miscarriage by other } \\
\text { people and through ritual was important. Men } \\
\text { reported that their primary role was to support } \\
\text { their partners. Participants who already had } \\
\text { living children coped better than those without. }\end{array}$ \\
\hline 11 & $\begin{array}{l}\text { O'Leary, } \\
2005\end{array}$ & $\begin{array}{l}\text { The Trauma } \\
\text { of Ultrasound } \\
\text { during a } \\
\text { Pregnancy } \\
\text { Following } \\
\text { Perinatal } \\
\text { Loss }\end{array}$ & $\begin{array}{l}\text { Journal of Loss } \\
\text { and Trauma }\end{array}$ & $\begin{array}{l}\text { United } \\
\text { States }\end{array}$ & $\begin{array}{l}\text { Descriptive } \\
\text { phenomenology. } \\
\text { Semi-structured } \\
\text { interviews. }\end{array}$ & $\begin{array}{l}9 \text { fathers who experienced } \\
\text { a perinatal loss and were in } \\
22 \text { to } 32 \text { weeks of gestation } \\
\text { of a current pregnancy. }\end{array}$ & $\begin{array}{l}\text { Explores how grief and symptoms of } \\
\text { posttraumatic stress disorder are } \\
\text { relived during the ultrasound } \\
\text { examination following a perinatal } \\
\text { loss. }\end{array}$ & $\begin{array}{l}\text { Men reported that prior to every ultrasound } \\
\text { they experienced anxiety. Participants had } \\
\text { difficulty separating past experience from } \\
\text { present pregnancy. Throughout ultrasounds, } \\
\text { memories of past loss were evoked. }\end{array}$ \\
\hline 12 & $\begin{array}{l}\text { O’Leary \& } \\
\text { Thorwick, } \\
2006\end{array}$ & $\begin{array}{l}\text { Fathers' } \\
\text { perspectives } \\
\text { during } \\
\text { pregnancy, } \\
\text { postperinatal } \\
\text { loss }\end{array}$ & $\begin{array}{l}\text { Journal of } \\
\text { Obstetric } \\
\text { Gynaecologic } \\
\text { and Neonatal } \\
\text { Nursing }\end{array}$ & $\begin{array}{l}\text { United } \\
\text { States }\end{array}$ & $\begin{array}{l}\text { Descriptive } \\
\text { phenomenology. } \\
\text { Semi-structured } \\
\text { interviews. }\end{array}$ & $\begin{array}{l}10 \text { men who had } \\
\text { experienced a pregnancy } \\
\text { loss in the previous year } \\
\text { and had a subsequent } \\
\text { pregnancy. }\end{array}$ & $\begin{array}{l}\text { Explore men's experiences and } \\
\text { perceptions of pregnancy after a } \\
\text { previous perinatal loss. }\end{array}$ & $\begin{array}{l}\text { Four themes: recognition, preoccupation, } \\
\text { stoicism and support. Men reported a desire to } \\
\text { be recognized by others for their loss. Mixed } \\
\text { reviews regarding support groups. }\end{array}$ \\
\hline 13 & $\begin{array}{l}\text { Rinehart \& } \\
\text { Kiselica, } \\
2010\end{array}$ & $\begin{array}{l}\text { Helping Men } \\
\text { Through the } \\
\text { Trauma of a } \\
\text { miscarriage }\end{array}$ & $\begin{array}{l}\text { Psychotherapy } \\
\text { Theory, } \\
\text { Research, } \\
\text { Practice } \\
\text { Training }\end{array}$ & $\begin{array}{l}\text { United } \\
\text { States }\end{array}$ & $\begin{array}{l}\text { Academic article with } \\
\text { reflections. }\end{array}$ & $\begin{array}{l}\text { Psychologist's case study } \\
\text { who experienced his } \\
\text { girlfriend's miscarriage } \\
\text { while in prison. }\end{array}$ & $\begin{array}{l}\text { Explores a psychologist's work with a } \\
\text { male client in prison who had } \\
\text { difficulty coping with his partner's } \\
\text { miscarriage. }\end{array}$ & $\begin{array}{l}\text { Suggests a male sensitive approach to } \\
\text { psychotherapy with men struggling with } \\
\text { miscarriage. Highlights that there are limited } \\
\text { socially acceptable ways for men to express his } \\
\text { grief. }\end{array}$ \\
\hline
\end{tabular}

This article is protected by copyright. All rights reserved 
Table 3. Summary of Results

\begin{tabular}{|c|c|c|c|c|c|c|c|c|}
\hline 14 & $\begin{array}{l}\text { Samuelsson, } \\
\text { Rådestad, \& } \\
\text { Segesten, } \\
\end{array}$ & $\begin{array}{l}\text { A waste of } \\
\text { life: fathers' } \\
\text { experience of } \\
\text { losing a child } \\
\text { before birth }\end{array}$ & BIRTH & Sweden & $\begin{array}{l}\text { Phenomenological } \\
\text { approach. Interviews. } \\
\text { Thematic analysis. }\end{array}$ & $\begin{array}{l}11 \text { men who had } \\
\text { experienced a stillbirth } 5 \\
\text { months to } 27 \text { months prior. }\end{array}$ & $\begin{array}{l}\text { Describe how fathers experienced } \\
\text { losing a child as a result of } \\
\text { intrauterine death. }\end{array}$ & $\begin{array}{l}\text { Fathers expressed frustration and helplessness. } \\
\text { Fathers found comfort in the care routine, } \\
\text { appreciated the tokens of remembrance. } \\
\text { Fathers had a new and fearful outlook on } \\
\text { pregnancy. }\end{array}$ \\
\hline 15 & $\begin{array}{l}\text { Wagner, } \\
\text { Vaughn, } \\
\text { Tuazon, \& } \\
\text { Tuazon, } 2018\end{array}$ & $\begin{array}{l}\text { Father's lived } \\
\text { experiences } \\
\text { of } \\
\text { miscarriage }\end{array}$ & $\begin{array}{l}\text { The Family } \\
\text { Journal: } \\
\text { Counselling and } \\
\text { Therapy for } \\
\text { Couples and } \\
\text { Families }\end{array}$ & $\begin{array}{l}\text { United } \\
\text { States }\end{array}$ & $\begin{array}{l}\text { Phenomenological } \\
\text { approach. Semi- } \\
\text { structured interviews. } \\
\text { Coded and themed. }\end{array}$ & $\begin{array}{l}11 \text { men who experienced a } \\
\text { miscarriage. }\end{array}$ & $\begin{array}{l}\text { Explores fathers' lived experiences of } \\
\text { miscarriage and describes themes } \\
\text { essential to that experience. }\end{array}$ & $\begin{array}{l}\text { Fathers viewed their role as a supporter, which } \\
\text { disfranchised them. Those who received } \\
\text { support expressed validation of their } \\
\text { experience. }\end{array}$ \\
\hline
\end{tabular}

This article is protected by copyright. All rights reserved 


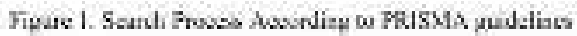
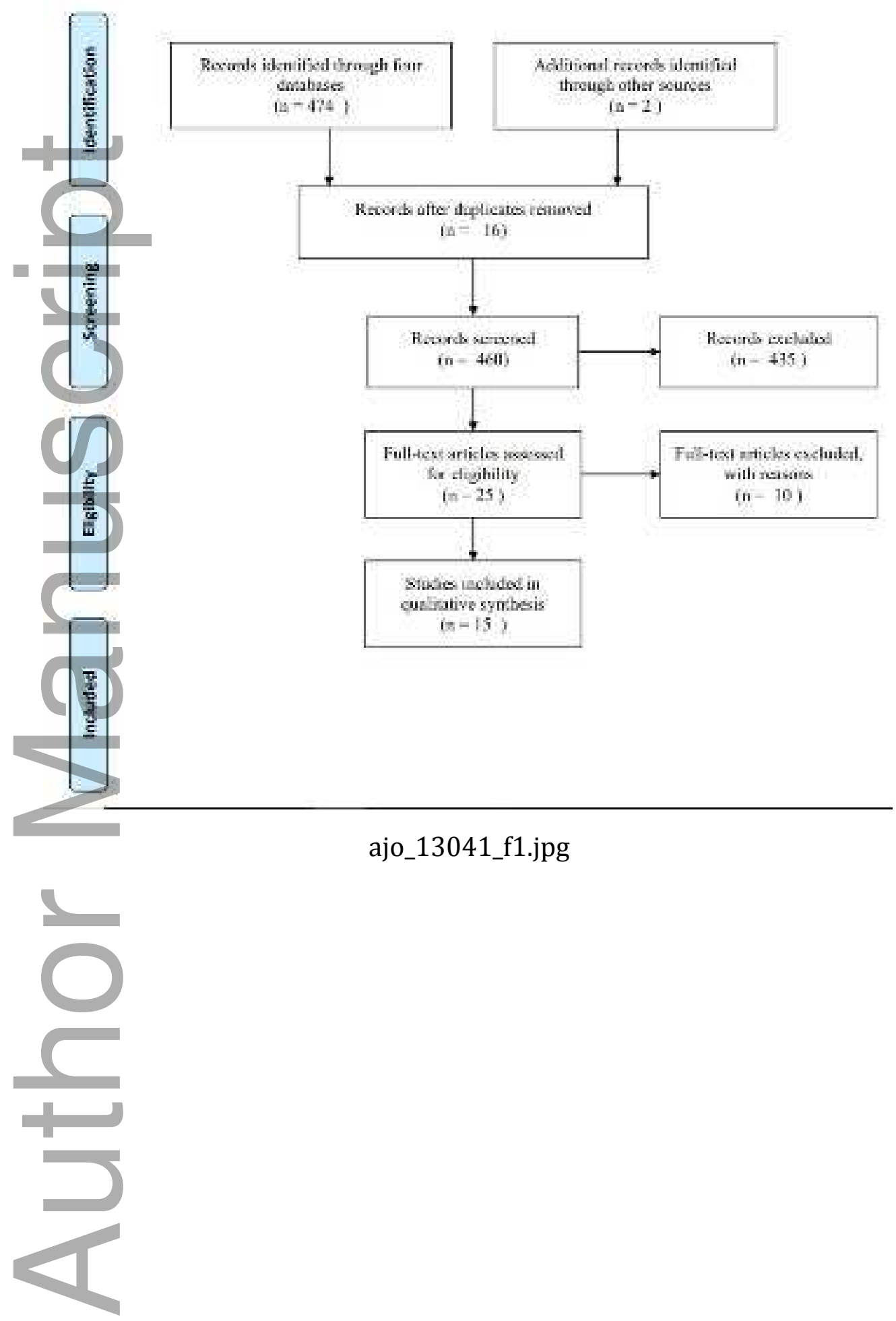
Figure 2. Key Themes and Subthemes

1. Pregnancy and the Aftermath

- Attachment In-Utero

- Identity Formation as a Father
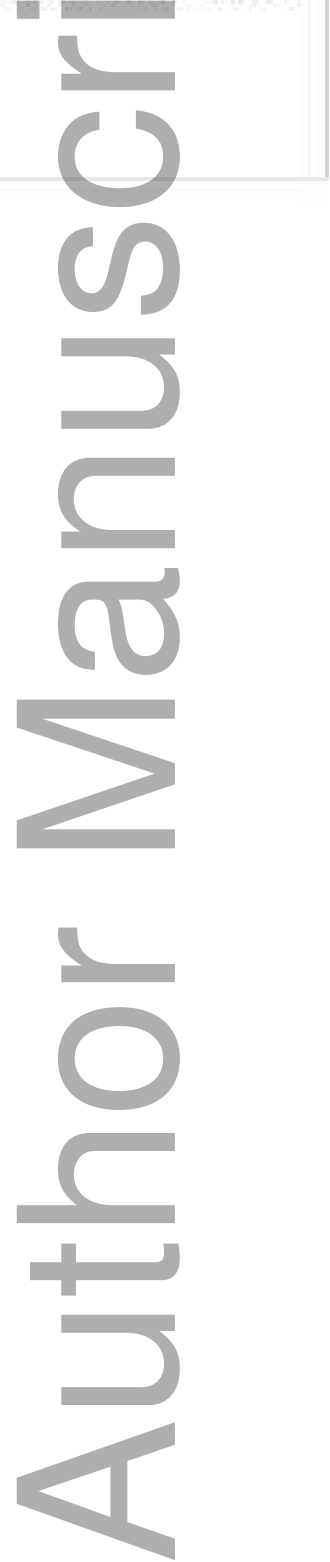

2. Supporting and Being Supported

- Supporting their Partner

- Being Supported by Friends, Family and Society
3. Impact Upon Future Pregnancies

- Coping with Uncertainty

- Positive Growth and Transformation

ajo_13041_f2.jpg 


\section{University Library}

\section{- M M N E R VA A gateway to Melbourne's research publications}

Minerva Access is the Institutional Repository of The University of Melbourne

Author/s:

Nguyen, V;Temple-Smith, M;Bilardi, J

Title:

Men's lived experiences of perinatal loss: A review of the literature

Date:

2019-08-15

Citation:

Nguyen, V., Temple-Smith, M. \& Bilardi, J. (2019). Men's lived experiences of perinatal loss: A review of the literature. AUSTRALIAN \& NEW ZEALAND JOURNAL OF OBSTETRICS \& GYNAECOLOGY, 59 (6), pp.757-766. https://doi.org/10.1111/ajo.13041.

Persistent Link:

http://hdl.handle.net/11343/286272 